\title{
Diagnoses of Patients Referring to a Child and Adolescent Psychiatry Outpatient Clinic
}

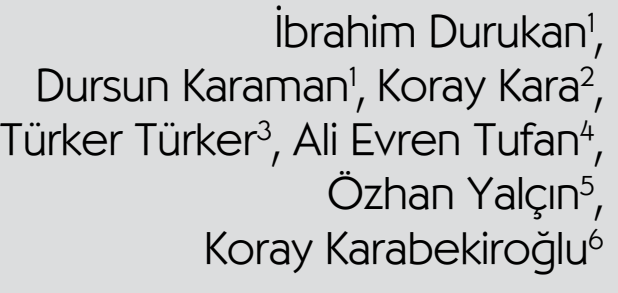

'Child and Adolescent Psychiatrist, ${ }^{2}$ Resident, Gülhane Military Medical Academy, Department of Child

Psychiatry, Ankara - Turkey

3Public Health Specialist, Gülhane Military Medical Academy, Department of Public Health, Ankara - Turkey ${ }^{4}$ Child and Adolescent Psychiatrist, Mental and Nervous Diseases Hospital, Department of Child and Adolescent Psychiatrist, Elazığ - Turkey

${ }^{5}$ Child and Adolescent Psychiatrist, Children's Hospital, Department of Child Psychiatry, Şanllurfa - Turkey ${ }^{6}$ Assoc. Prof. Dr., 19 Mayıs University Medical School, Department of Child Psychiatry, Samsun - Turkey

\section{ABSTRACT}

Diagnoses of patients referring to a child and adolescent psychiatry outpatient clinic Objective: The aim of the present study is to identify the diagnoses of patients who referred to a child and adolescent psychiatry outpatient clinic.

Method: Medical records of 538 patients referred to the Children and Adolescent Psychiatry outpatient clinic at Gulhane Military Medical School, between January 2009 and June 2009 were studied retrospectively.

Results: It was found that the patients were mostly male and within 7 to 18 years of age. It was also determined that three quarters of patients had at least one diagnosis and the diagnosis rate in children between the ages of $0-6$ was 50 percent. Comorbid diagnoses were found in 13.7 percent of all cases and they were mainly in the attention deficit hyperactivity disorder (ADHD) group. The most common diagnoses were ADHD, generalized anxiety disorder, mental retardation, depression and enuresis, respectively. The most common diagnosis in all age subgroups was ADHD. While the most common diagnoses in boys are ADHD, mental retardation, generalized anxiety disorder, enuresis and depression respectively, they were ADHD, generalized anxiety disorder, depression, mental retardation and enuresis in girls.

Conclusion: To know the most common diagnoses, diagnosis differences within genders and possible diagnoses for certain age groups will be useful for improving child and adolescent psychiatry services.

Key words: Child, adolescent, diagnoses

\section{ÖZET}

Çocuk ve ergen psikiyatrisi polikliniğine başvuran hastalarda tanı dağıımı

Amaç: Bu araşııımada çocuk ve ergen psikiyatrisi polikliniğine başvuran hastaların tanı dağlımlarının saptanması amaçlanmıştır.

Yöntem: GATA Çocuk Ruh Sağlığı ve Hastalıkları Anabilim Dalı Polikliniğine Ocak 2009-Haziran 2009 tarihleri arasında başvuran 538 hastanın dosyaları geriye dönük olarak incelenmiştir.

Bulgular: Olguların daha çok erkek olduğu ve 7-18 yaş grubu çocuk ve ergenlerden oluştuğu saptanmıştır. Başvuran olguların dörtte üçüne, bir ya da birden çok tanı konduğu, 0-6 yaş arası olgularda ise tanı konma oranının \%50 olduğu görülmüştür. Olguların \%13.7'sinde eştanı saptanmış, eștanı saptanma oranının en sık dikkat eksikliğ hiperaktivite bozukluğu (DEHB) grubunda olduğu belirlenmiştir. Tüm olgular göz önüne alındığında, en sık saptanan tanıların, sırasıyla DEHB, yaygın anksiyete bozukluğu, zeka geriliği, depresyon ve enürezis olduğu, tüm yaş gruplarında en sık DEHB tanısı konduğu, erkek çocuklarda en sık DEHB, zeka geriliği, yaygın anksiyete bozukluğu, enürezis ve depresyon; kızlarda ise DEHB, yaygın anksiyete bozukluğu, depresyon, zeka geriliği ve enürezis saptanmıştır.

Sonuç: SIk saptanan tanıların bilinmesi, cinsiyetler arası tanı farklılıklarının ve yaş gruplarına göre olası tanıların belirlenmesi, çocuk ve ergen psikiyatrisi poliklinik hizmetlerinin iyileştirilmesine katkıda bulunacaktır.

Anahtar kelimeler: Çocuk, ergen, tanılar
Address reprint requests to:

Child and Adolescent Psychiatrist ibrahim Durukan, Gülhane Military Medical Academy, Department of Child Psychiatry, Etlik, Ankara - Türkiye

Phone: +90-312-304-4565

E-mail address: idurukan2003@yahoo.com

Date of receipt: December 13, 2010

Kabul tarihi / Date of acceptance: January 25, 2011

\section{INTRODUCTION}

C hild and adolescent psychiatry outpatient clinics have an important role in diagnosis and treatment of various mental disorders. Mental disorders significantly affect quality of life of both the individual, and family of children and adolescents like in adults. It was shown in epidemiological studies that mental disorders are widely 
seen in children and adolescents today and admissions to child and adolescent psychiatry outpatient clinics are rapidly increasing. For this reason, early diagnosis and treatment of mental disorders in children and adolescents seems to be important for child and adolescent psychiatry practice.

Although area of interest of child and adolescent psychiatry covers only the first 18 years of life, this time interval contains five out of eight stages of Erickson's mental-social theory and all stages of classical psychoanalytical theory. Currently it is widely accepted that effects of mental problems starting in childhood are not limited to childhood and adolescence but continue in adulthood as well.

Only $10-22 \%$ of children and adolescents having a psychiatric disorder and applying to first level healthcare facilities are diagnosed and this points out that this age group does not often receive appropriate mental healthcare. However, it is already known that psychiatric disorders of children and adolescents can generally be treated by appropriate approaches and their social and academic functionality improve consequently (1).

Referrals to child and adolescent psychiatry outpatient clinics, symptoms and distribution of diagnoses were evaluated in several studies (2-4). In a population-based study, prevalence of mental disorders in children who were under 18 years old and in adolescent age group was found $15.8 \%$ (5). Prevalence of mental problems in 4-18 age group in a population sample in Turkey was reported as $11.3 \%$ by parents (6). In other studies done in children and adolescents, prevalence of psychiatric diagnoses was found between $9.5 \%$ and $19.8 \%$ (7-10). Even in developed countries, only one fifth of children having severe mental problems can get mental healthcare despite these high prevalence rates (11).

Stoller reported that (12) most frequent diagnoses in children and adolescents referring to child psychiatry outpatient clinics are expressive disorders (attention deficit/hyperactivity disorder, conduct disorder) followed by introversion disorders (anxiety disorder, depression). Aras et al reported that (3) most prevalent diagnoses in boys are attention deficit/hyperactivity disorder (ADHD) $(17.8 \%)$, enuresis $(9.5 \%)$, mental retardation (MR) (7.1\%), anxiety disorders $(7.1 \%)$ and depression (5.9\%); most prevalent diagnoses in girls are anxiety disorders (12.7\%), depression (10.2\%), enuresis $(9.5 \%), \mathrm{MR}(7.4 \%)$ and $\mathrm{ADHD}(4.6 \%)$. Aktepe et al. reported that (4) most prevalent diagnoses in boys are ADHD (15.8\%), depression (12.4\%), enuresis $(9.7 \%)$, anxiety disorders $(8.5 \%)$ and adjustment disorder (8.3); most prevalent diagnoses in girls are depression (21.9\%), anxiety disorders (12.6\%), enuresis $(11.4 \%)$, adjustment disorder $(8.5 \%)$ and $\mathrm{ADHD}$ $(5.2 \%)$.

Awareness of distribution and prevalence of mental problems in children provides basic data to determine areas of preventive measures and treatment services. Effective programs towards improvement of child mental health services can be developed by bringing up this need of high priority (11). In this study, we aimed to investigate diagnoses of patients admitted to child and adolescent psychiatry outpatient clinic of Gülhane Military Medical Academy (GATA).

\section{METHODS}

In this study, files of 548 patients admitted to GATA Department of Child Mental Health and Diseases during 6 month period between January 2009 and June 2009 were retrospectively evaluated. These 548 patients were examined by three different child and adolescent psychiatrists. Files of 10 patients were excluded from the study due to significant lack of information. Files of remaining 538 patients were included in the study group. Evaluation was based on recorded semi-structured interview form in which information was obtained from family and patient at the first admission to outpatient clinic, patient file and psychiatric examination information. Distribution according to gender, age and diagnostic groups of evaluated cases were determined. Psychiatric diagnoses of referred patients were done according to DSM-IV by physicians who examined patients with clinical interview of mean 45 minutes. Cases were examined in 3 sub-groups as ages of 0-6, 7-11 and 12-18. 


\section{Statistical Analysis}

Data were analyzed by SPSS 11.0 (Statistical Package for the Social Sciences) software. Number, percent, mean and standard deviation were used as descriptive statistics. Data were analyzed by chi-square tests. Statistical significance was taken as $p<0.05$ at all analyses.

\section{RESULTS}

Files of 538 patients were included in the study. $58.7 \%$ of cases were boys $(n=316)$ and $41.3 \%$ were girls $(n=222) .28 .4 \%$ of cases were $0-6$ years old, $41.4 \%$ were $7-12$ years old, $30.2 \%$ were $12-18$ years old. Out of these cases, $74.7 \%(n=402)$ were diagnosed and remainder $25.3 \%(n=136)$ were not diagnosed. Diagnosis rates according to age groups were given in table 1 (Table 1).

When cases with multiple diagnoses were evaluated, total 73 cases $(13.6 \%)$ had multiple diagnoses with 6 cases between 0-6 years old, 36 cases between 7-11 years old and 31 cases between 12-18 years old. Most

\begin{tabular}{|c|c|c|c|c|}
\hline \multirow[t]{2}{*}{ Age group } & \multicolumn{2}{|c|}{ Cases diagnosed } & \multicolumn{2}{|c|}{ Cases not diagnosed } \\
\hline & $\mathbf{n}$ & $\%$ & $\mathbf{n}$ & $\%$ \\
\hline $0-6$ years $(n=153)$ & 77 & 50.3 & 76 & 49.7 \\
\hline $7-11$ years $(n=223)$ & 185 & 82.9 & 38 & 17.1 \\
\hline $12-18$ years $(n=162)$ & 140 & 86.4 & 22 & 13.6 \\
\hline Total $(\mathrm{n}=538)$ & 402 & 74.7 & 136 & 25.3 \\
\hline
\end{tabular}

frequent comorbid diagnosis were seen in $\mathrm{ADHD}$ cases $(n=46)$. Comorbid diagnoses of ADHD and specific learning disorder (SLD) were seenin 14 cases, ADHD and generalized anxiety disorder (GAD) in 8 cases, $\mathrm{ADHD}$ and enuresis (EN) in 6 cases, $\mathrm{ADHD}$ and communication disorders in 5 cases, ADHD and depression in 4 cases, $\mathrm{ADHD}$ and mild MR in 4 cases, conduct disorder, encopresis, chronic motor or vocal tic disorder, obsessive-compulsive disorder (OCD) and generalized developmental disorder-unidentified (GDD-U) in one case. The most prevalent comorbid diagnosis except ADHD was mild $M R$ and communicative disorder in 3 cases.

When all age groups were considered, most prevalent diagnoses were $\mathrm{ADHD}, \mathrm{GAD}, \mathrm{MR}$, depression and $\mathrm{EN}$, consecutively. Most prevalent DSM-IV axis I and II diagnoses and their prevalence were given in table 2 (Table 2).

Table 2: Most prevalent diagnoses and their rates

\begin{tabular}{lcc} 
DSM-IV Axis I or II diagnoses & $\begin{array}{c}\text { Cases diagnosed } \\
(\mathbf{n = 5 3 8 )}\end{array}$ & $\mathbf{~ \% ~}$ \\
\hline 1. ADHD & 143 & 26.5 \\
2. Generalized anxiety disorder & 38 & 7.0 \\
3. Mental retardation & 31 & 5.7 \\
4. Depression & 28 & 5.2 \\
5. Enuresis & 27 & 5.0 \\
6. Specific learning disorder & 21 & 3.9 \\
7. Social phobia & 17 & 3.1 \\
8. Obsessive compulsive disorder & 15 & 2.7 \\
9. Fonolojik bozukluk & 15 & 2.7 \\
10. GDD-U & 12 & 2.2 \\
\hline
\end{tabular}

ADHD: Attention Deficit Hyperactivity Disorder

GDD-U: Generalized Developmental Disorder-Unclassified

Table 3: First 10 most prevalent DSM-IV axis I and II diagnoses according to age groups

\begin{tabular}{|c|c|c|}
\hline $0-6$ years $(n=76)$ & $7-11$ years $(n=185)$ & $12-18$ years $(n=140)$ \\
\hline 1. $\mathrm{ADHD}(\mathrm{n}=12)$ & 1. $\operatorname{ADHD}(n=85)$ & 1. $\mathrm{ADHD}(\mathrm{n}=46)$ \\
\hline 2. GDD-U $(n=10)$ & 2. GAD $(n=19)$ & 2. Depression $(n=22)$ \\
\hline 3. Verbal Expression Disorder $(n=8)$ & 3. Enuresis $(n=17)$ & 3. $\mathrm{GAD}(\mathrm{n}=18)$ \\
\hline 4. Autistic Disorder $(n=7)$ & 4. Mild MR (n=14) & 4. Social Phobia $(n=12)$ \\
\hline 4. Phonological Disorder $(n=7)$ & 5. $\operatorname{SLD}(n=12)$ & 5. $\mathrm{OCD}(\mathrm{n}=11)$ \\
\hline 6. Enuresis $(n=6)$ & 6. Phonological Disorder $(n=6)$ & 6. $\operatorname{SLD}(\mathrm{n}=7)$ \\
\hline 7. Stuttering $(n=4)$ & 7. Stuttering $(n=5)$ & 7. Mild MR ( $n=6)$ \\
\hline 8. Mild MR ( $n=4)$ & 8. Depression $(n=5)$ & 8. Conduct Disorder (CD) $(n=5)$ \\
\hline 9. Masturbation $(n=3)$ & 9. Borderline Intelligence $(n=5)$ & 9. Enuresis $(n=4)$ \\
\hline 10.Articulation Disorder $(\mathrm{n}=2)$ & 10. $\mathrm{OCD}(\mathrm{n}=4)$ & 9. Tic Disorders $(n=4)$ \\
\hline
\end{tabular}

ADHD: Attention Deficit Hyperactivity Disorder, GAD: Generalized Anxiety Disorder GDD-U: Generalized Developmental Disorder-Unclassified

MR: Mental Retardation, SLD: Specific Learning Disorder, OCD: Obsessive Compulsive Disorder 
Table 4: Most frequent diagnoses and their distribution according to gender

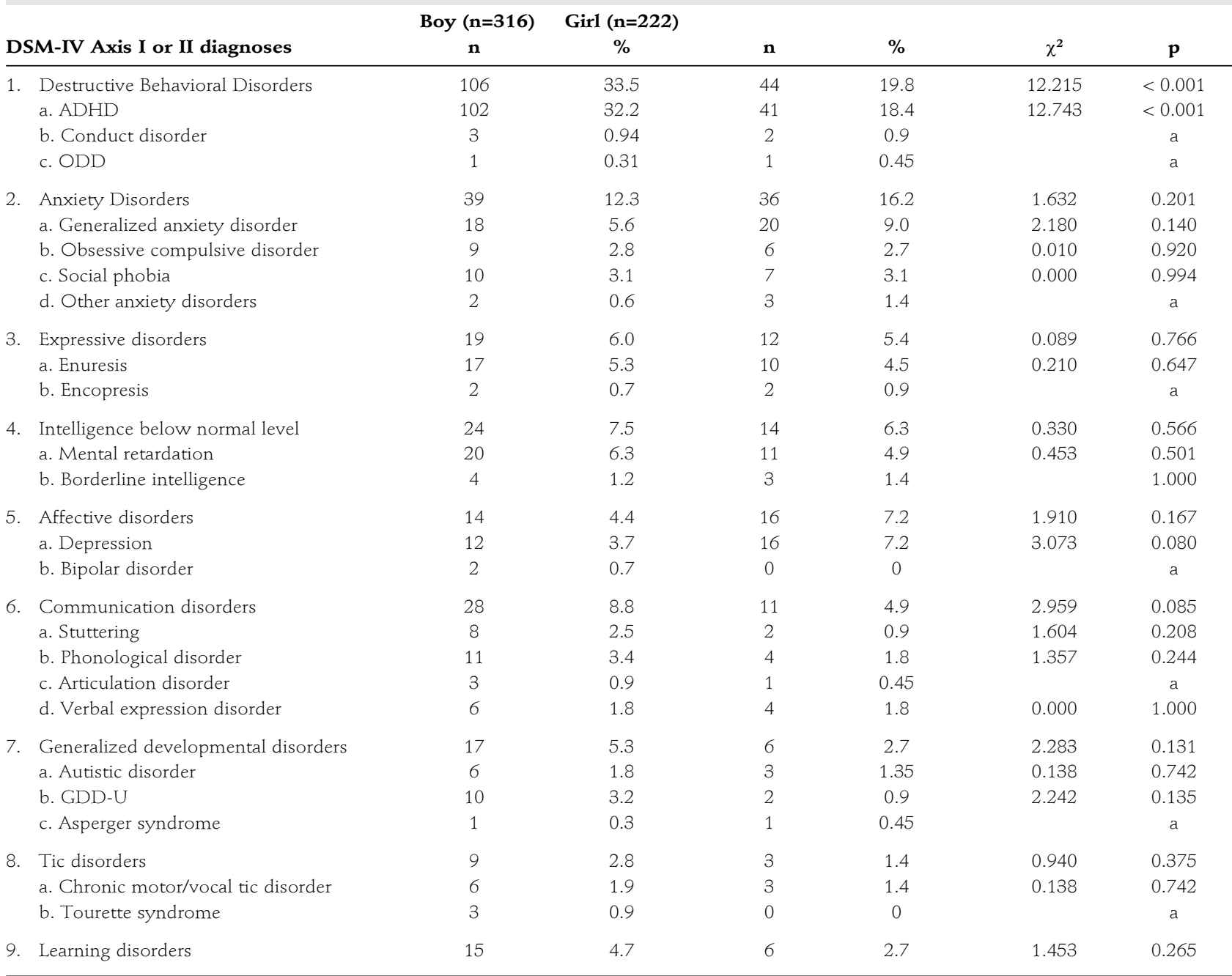

a, $p$ value could not be calculated due to inadequate number of cases. $\chi^{2}$, Chi square

ODD: Oppositional Defiant Disorder, ADHD: Attention Deficit Hyperactivity Disorder

GDD-U: Generalized Developmental Disorder-Unclassified

When most prevalent diagnoses according to age groups were examined, ADHD was in the first rank at all three age groups. GDD-U and verbal expression disorder follow ADHD in 0-6 age group, GAD and EN in 7-11 age group and depression and GAD in 12-18 age group. First 10 DSM-IV axis I and II diagnoses according to age groups were given in table 3 (Table 3 ).

$\mathrm{ADHD}, \mathrm{MR}, \mathrm{GAD}, \mathrm{EN}$ and depression were most prevalent diagnoses in boys and ADHD, GAD, depression, $\mathrm{MR}$ and $\mathrm{EN}$ were most prevalent diagnoses in girls, consecutively. Most prevalent diagnoses and distribution of them according to age groups were given in table 4 (Table 4).

\section{DISCUSSION}

In our study, most prevalent diagnosis among cases admitted to child and adolescent psychiatry outpatient clinic was found as ADHD, number of boys was higher and referrals were higher at school age and adolescence.

Mostly boys are referred to child and adolescent psychiatry outpatient clinic (13). Research done at four different child psychiatry clinic in Turkey showed that $61.5 \%$ to 66.95 of cases are boys (4,13-15). HarpazRotem and Rosenheck (2) reported in their study which included 40,000 children that $60.8 \%$ of cases are boys. Recart et al. (16) reported that $53.2 \%$ of 376 cases 
referred to a child and adolescent psychiatry clinic were boys. Proportion of $57.8 \%$ found in our study seems to be consistent with literature. Higher referral rates of boys to mental health outpatient clinics compared to girls in general population seem to be related to later starting and ending maturation of boys compared to girls (13).

Harpaz-Rotem and Rosenheck (2) reported that out of nearly 40,000 children referred for mental healthcare, $13 \%$ were between $0-6$ years old, $41 \%$ were between 7-12 years old and 46\% were between $13-18$ years old. Aras et al. (3) found these rates $23 \%, 43.7 \%$ and $33.3 \%$, consecutively. Tanriöver et al. (13) found that most frequent referrals are from 6-11 age group and Aktepe et al. (4) reported that 7-12 age group are referred most. In our study these rates were found $28.4 \%$ (0-6 years), $41.4 \%$ (7-11 years) and $30.2 \%$ (12-18 years), consecutively. When all these studies are evaluated altogether, majority of referrals are at primary school age and adolescence, although age groups of highest prevalence of referrals vary in different studies, referral rates are very close to each other in 7-11 and 12-18 age groups. High referral rates at these periods may be related to adjustment problems occurring in school starting period and behavioral problems in adolescence.

In this study, $74.7 \%$ of all cases were diagnosed, but remainder $25.3 \%$ did not take any psychiatric diagnosis. Aktepe et al.(4) reported that at least one diagnosis was made in $87.3 \%$ of cases and remaining $12.7 \%$ had normal characteristics and Aras et al. (3) reported that $85.1 \%$ of cases had at least one diagnosis and remaining $14.9 \%$ had normal characteristics. Higher proportion of cases evaluated as normal in our study compared to the two studies above may be due to higher probability of referral of more severe cases to child and adolescent psychiatry outpatient clinics of these university hospitals and referrals from different socio-economic levels; however, only families of a specific profession can be referred to the clinic where this study was done. Referrals from a specific profession might have caused a higher socio-economic level and consequent higher number of referrals for consultation.

$5.3 \%$ of cases between the ages of 0 and $6,82.9 \%$ of cases between the ages of 7 and 11 , and $86.4 \%$ of cases between the ages of 12 and 18 had one or more than one diagnosis. In child psychiatry outpatientadmissions, evaluation of mental skills, learning levels, lingual skills, adjustment skills, visual-motor coordination and personality characteristics have great importance (17). Especially not having any diagnosis in half of admissions at pre-school period may be related to admissions to get above characteristics to be evaluated. In a study by Görker et al. (18) which evaluated symptoms and diagnoses of 1079 adolescents between the ages of 12 and 18 , diagnosis rate of cases was found $81.5 \%$. This number is consistent with $86.4 \%$ rate found for the same age group in our study. However, Görker et al. also evaluated axis III diagnoses but we only evaluated axis I and II diagnoses.

In our study, it was found that $13.6 \%$ of our cases $(n=73)$ had comorbid diagnoses. Comorbid diagnosis rates were found $15.29 \%, 25 \%$ and $28.7 \%$, consecutively in three studies done with children and adolescents $(3,4,18)$. In a study done abroad, this figure was reported as $29.9 \%$ (19). It was reported that comorbid diagnoses increase severity of the disease, cause more chronic course and impair psychosocial functionality and more evident impairment in quality of life (20). Comorbid diagnosis rate found in this study is similar to the results of the study which Görker et al. did with adolescents only but it may also be related to lower number of studies examined both child and adolescent age groups, higher number of normal cases in our study compared to other studies and limited patient profile admitted to our outpatient clinic. Not getting comorbid diagnoses seems to be possible due to not using semi-structured interview forms for diagnosis as well.

Recart et al. (16) mainly found ADHD, other destructive behavioral disorders, adjustment disorders mood and anxiety disorders in cases admitted to child and adolescent psychiatry clinics. Harpaz-Rotem and Rosenheck (2) reported that most prevalent diagnoses were $\mathrm{ADHD}$, depression and anxiety disorder; in the same study they reported that depression and anxiety disorders increase in time. Aras et al. (3) found that most prevalent diagnoses were $\mathrm{ADHD}$, EN and anxiety disorders, depression and MR, consecutively; Aktepe et al. (4) reported that most prevalent axis I and II diagnoses 
were depression, anxiety disorders, EN, ADHD and adjustment disorders, consecutively. Most prevalent diagnoses we found in our study were ADHD, GAD, $\mathrm{MR}$, depression and $\mathrm{EN}$ and these findings are consistent with the literature. Detecting oppositional defiant disorder (ODD) only in 2 out of 538 cases may be related to not putting diagnoses with structured clinical interview, frequent concordance of ODD with $\mathrm{ADHD}$, neglecting ODD diagnosis due to diagnosis and treatment of ADHD. Differences in frequencies may be due to sample sizes and socio-economic characteristics of patients admitted to child psychiatry outpatient clinics where these studies were done.

In our study, most prevalent diagnosis we detected according to age groups was $\mathrm{ADHD}$ for each three age groups. In 0-6 age group GDD-U and verbal expression disorder follows ADHD, in 7-11 age group GAD and EN follow, consecutively and in 12-18 age group depression and GAD follow, consecutively. HarpazRotem and Rosenheck (2) divided cases in their sample into three sub-groups and evaluated them twice in 1995 and 2000 for diagnostic purposes. They found that in both evaluations at 0-6 age group, most prevalent diagnoses were $\mathrm{ADHD}$, adjustment disorder and anxiety disorders, in the second evaluation performed 5 years later, autism diagnoses were found significantly higher in boys. In our study, autism and GDD-U were among five most prevalent diagnoses in 0-6 age group.

In both evaluations at 7-12 age group, first two most prevalent diagnoses were ADHD and adjustment disorder, however in the third rank there was mild depression in boys and anxiety disorders in girls. In our study, enuresis was diagnosed more compared to this study. This difference may be related to sample size of our study which is 80 times smaller than the sample size of the mentioned study. Moreover, diagnoses in "other diagnoses" sub-title of diagnostic groups of Harpaz-Rotem and Rosenheck study (2) were not declared.

In the same study, $\mathrm{ADHD}$, adjustment disorder and mild depression were found consecutively at boys from 13-18 age group and adjustment disorder, mild depression and depression were found consecutively at girls from the same age group. In the second evaluation of 7-12 and 13-18 age groups performed five years later, more cases were found to get anxiety disorders and ADHD.

In their study which evaluated diagnoses of children and adolescents in 12-18 age group Görker et al. (18) found that most frequent diagnoses were anxiety disorder, mood disorder, MR, expression disorders and destructive conduct disorder, consecutively. In our study, most prevalent diagnoses were ADHD, depression, GAD, social phobia and OCD, consecutively. Diagnostic groups were similar with results of the study of Görker et al. except ADHD.

It is already known that in population sample, expressiveand communicative disorders (aggressiveness, criminal behaviors and $\mathrm{ADHD}$ ) are more prevalent in boys and introversion problems (retraction, somatic complaints, anxiety, depression) are more prevalent in girls (21-23). In a study done abroad, destructive behavioral disorders are observed 3 times more in boys than girls (24). Girls get affective and anxiety disorder diagnoses more frequently and destructive behavioral disorders are seen less frequently $(25,26)$.

Frequent diagnosis of anxiety and depression in girls and $\mathrm{ADHD}$ in boys referred to child and adolescent psychiatry outpatient clinic in our study are consistent with literature but the most prevalent diagnosis of $\mathrm{ADHD}$ in girls is discrepant with the literature. This inconsistency may be related to relative low number of cases in the sample. ADHD is diagnosed later in girls compared to hyperactive and impulsive ADHD cases due to commencement of attention deficit which is frequently reported in girls after seven years of age $(27,28)$. However, child psychiatry training is getting widespread in our country and number of specialists is increasing and this may also increase diagnoses at girls referring with complaints suggesting ADHD. Evident impairment in functionality also direct families towards seeking treatment although diagnostic criteria may not be fully met (29). This search for treatment might also have increased number of ADHD diagnoses in girls. This finding should be re-evaluated in studies with wider samples. Among the most prevalent diagnoses in our study were anxiety disorders, EN and MR after 
$\mathrm{ADHD}$ in boys and anxiety disorders, depression, EN and $M R$ in girls seem to be consistent with literature $(3,4)$.

Absence of diagnosis of alcohol and substance abuse disorder in any of the cases in our study may be related to presence of diagnosis and treatment centers specific to alcohol and substance abuse disorders, diagnosis of conduct disorder in cases with alcohol and substance abuse in this study and probable negligence of comorbid alcohol-substance abuse disorder.

In this study, our main focus was diagnoses of cases and their initial complaints and socio-demographic data were not evaluated, diagnoses were not done with structured scales and covering not only cases first referred but also cases applied for control visits are limitations of this study. However, to our knowledge,

\section{REFERENCES}

1. World Health Organization. Child and Adolescent Mental Health Policies and Plans. WHO Library Cataloguing-in-publication Data. Mental Health Policy and Services Guidance Package, 2005.

2. Harpaz Rotem I, Rosenheck RA. Changes in outpatient psychiatric diagnosis in privately insured children and adolescents from 1995 to 2000. Child Psychiatry Hum Dev 2004; 34:329-340.

\section{rossef}

3. Aras Ş, Ünlü G, Taş FV. Çocuk ve ergen psikiyatrisi polikliniğine başvuran hastalarda belirtiler, tanılar ve tanıya yönelik incelemeler. Klinik Psikiyatri Dergisi 2007; 10:28-37 (Article in Turkish)

4. Aktepe E, Demirci K, Çalışkan AM, Sönmez Y. Symptoms and diagnoses of patients referring to a child and adolescent psychiatry polyclinic Düşünen Adam The Journal of Psychiatry and Neurological Sciences 2010; 23:100-108.

5. Roberts RE, Attkisson CC, Rosenblatt A. Prevalence of psychopathology among children and adolescents. Am J Psychiatry 1998; 155:715-725.

6. Erol N, Şimşek Z. Türkiye ruh sağlı̆̆ı profili. Çocuk ve gençlerde ruh sağlığı: yeterlik alanları, davranış ve duygusal sorunların dağılımı: İçinde Erol N, Kılıç C, Ulusoy M, Keçeci M, Şimşek Z Türkiye Ruh Sağlığı Raporu (Hazırlayanlar). Ankara: Sağlık Bakanlığı, 1998, 25-75 (Article in Turkish).

7. Costello EJ, Mustillo S, Erkanli A Keeler G, Angold A. Prevalence and development of psychiatric disorders in childhood and adolescence. Arch Gen Psychiatry 2003; 60:837-844.

Crosser evaluation of child and adolescent cases by age groups first time in our country can be evaluated as the strong part of our study.

\section{CONCLUSION}

In this study it was observed that mostly boys are referred to child psychiatry and referral frequency was higher in 7-11 and 12-18 age groups. Results of this study point out that diagnostic differences between genders and probable diagnoses according to age groups should be considered. Also, it is suggested that awareness of frequent diagnoses guides in diagnosis and treatment processes. Findings from this study may be developed by studies with wider samples having higher number of cases in sub-groups.

8. Ford T, Goodman R, Meltzer H. The British child and adolescent mental health survey 1999: the prevalence of DSM-IV disorders. J Am Acad Child Adolesc Psychiatry 2003; 42:1203-1211. Crossers

9. Canino G, Shrout PE, Rubio-Stipec M, Bird HR, Bravo M, Ramirez R, Chavez L, Alegria M, Bauermeister JJ, Hohmann A, Ribera J, Garcia P, Martinez-Taboas A. The DSM-IV rates of child and adolescent disorders in Puerto Rico: prevalence, correlates, service use, and the effects of impairment. Arch Gen Psychiatry 2004; 61:85-93

\section{erosser}

10. Lehmkuhl L, Köster I, Schubert I. Outpatient care for child and adolescent psychiatric disorders-data from an insuree-related epidemiological study. Prax Kinderpsychol Kinderpsychiatr 2009; 58:170-185.

11. Offord DR, Bennett KJ. Epidemiology and prevention: In Lewis $M$ (editor). Child and adolescent psychiatry. A Comprehensive Textbook. Third edition. USA: Lippincott Williams Wilkins, 2002, 1320-1335.

12. Stoller JA. Diagnostic profiles in outpatient child psychiatry. Am J Orthopsychiatry 2006; 76:98-102.

\section{crossef}

13. Tanrı̈̈ver S, Kaya N, Tüzün Ü, Aydoğmuş K. Çocuk psikiyatrisi polikliniğine başvuran çocukların demografik özellikleri ile ilgili bir çalışma. Düşünen Adam Psikiyatri ve Nörolojik Bilimler Dergisi 1992; 5:13-19 (Article in Turkish).

14. Epir N. Bir çocuk sağllğ̆ kliniğine başvuran çocuklarla ilgili incelemeler. 10. Milli Psikiyatrik ve Nörolojik Bilimler Kongresi Özet Kitabı, 1974, 161-164 (Article in Turkish). 
15. Sonuvar B, Yörükoğlu A, Öktem F, Akyıldız S. Hacettepe çocuk ruh sağlığı kliniğinde iki yıl içinde görülen çocukların demografik özellikleri. Psikoloji Dergisi 1982; 13:33-39 (Article in Turkish).

16. Recart C, Castro P, Alvarez H, Bedregal P. Characteristics of children and adolescents attended in a private psychiatric outpatient clinic. Rev Med Chil 2002; 130: 295-303.

17. Moss NE, Racusin GR. Psychological assessment of children and adolescents: In Lewis $M$ (editor). Child and adolescent psychiatry. A Comprehensive Textbook. Third edition. USA: Lippincott Williams Wilkins, 2002, 555-573.

18. Görker I, Korkmazlar Ü, Durukan M, Aydoğdu A. Çocuk ve ergen psikiyatri kliniğine başvuran ergenlerde belirti ve tan dağılımı. Klinik Psikiyatri Dergisi 2004; 7:103-110 (Article in Turkish).

19. Al-Jawadi AA, Abdul-Rhman A. Prevalence of childhood and early adolescence mental disorders among children attending primary health care centers in Mosul, Iraq: a cross sectional study. BMC Public Health 2007; 7:274.

\section{erossers}

20. Cloninger CR. Comorbidity of anxiety and depression. J Clin Psychopharmacol 1990; 10 (Suppl.3):43-46.

21. Verhulst FC, Achenbach TM, van der Ende J Verhulst FC, Achenbach TM, van der Ende J. Comparison of problems reported by youths from seven countries. Am J Psychiatry 2003; 160:1479-1485.

\section{Crossef}

22. Erşan EE, Doğan $O$, Doğan S Sümer H. The distribution of symptoms of attention-deficit/hyperactivity disorder and oppositional defiant disorder in school age children in Turkey. Eur Child Adolesc Psychiatry 2004; 13:354-361.

\section{erossef}

23. Benenson JF. Sex differences: In Hopkins B (editor). The Cambridge Encyclopedia of Child Development. UK: Cambridge University Press, 2005, 366-374.

24. Fombonne E. The Chartres Study: I. Prevalence of psychiatric disorders among French school-age-children. Br J Psychiatry 1994; 164:69-79.

\section{Crosuef}

25. Fettahoğlu Ç, Özatalay E. Çocuklarda hareketlilik ve/veya dikkatsizlik yakınmaları ve dikkat eksikliği hiperaktivite bozukluğu tanısı. Çocuk ve Gençlik Ruh Sağlığı Dergisi 2006; 13:13-18 (Article in Turkish).

26. Roberts RE, Roberts CR, Xing Y. Rates of DSM-IV psychiatric disorders among adolescents in a large metropolitan area. J Psychiatr Res 2007; 41:959-967.

\section{crosser}

27. Applegate B, Lahey BB, Hart EL, Biederman J, Hynd GW, Barkley RA ve ark. Validity of the age-of- onset criterion for ADHD: a report from the DSM-IV field trials. J Am Acad Child Adolesc Psychiatry 1997; 36:1211-1221.

\section{rosser}

28. Barkley RA, Biederman J. Toward a broader definition of the age-of-onset criterion for attention-deficit hyperactivity disorder. J Am Acad Child Adolesc Psychiatry 1997; 36: 1204-1210.

\section{rossef}

29. Angold A, Costello EJ, Farmer EM, Burns BJ, Erkanli A. Impaired but undiagnosed. J Am Acad Child Adolesc Psychiatry 1999; 38:129-137.

\section{crosses}

